\title{
Non-Sustained Ventricular Tachycardia by ECG Finding
}

National Cancer Institute

\section{Source}

National Cancer Institute. Non-Sustained Ventricular Tachycardia by ECG Finding. NCI

Thesaurus. Code C71053.

An electrocardiographic finding of ventricular tachycardia less than 30 seconds in duration. 